\title{
\begin{tabular}{l|l|l} 
Jurnal Eksplorasi Akuntansi & e-ISSN : 2656-3649 (Online) \\
Vol. 3, No 1, Februari 2021, Hal 98-111 & http://jea.ppj.unp.ac.id/index.php/jea
\end{tabular}
}

\section{Pengaruh Opini Audit, Kebijakan Hutang, Dan Pertumbuhan Perusahaan Terhadap Nilai Perusahaan}

\author{
Idris Fadhillah ${ }^{1}$, Mayar Afriyenti ${ }^{2}$ \\ 1,2 Jurusan Akuntansi Fakultas Ekonomi Universitas Negeri Padang \\ *Korespondesi: idrisfadillah@gmail.com
}

\begin{abstract}
The purpose of this study is to analyze: (1) The effect of audit opinion on firm value. (2) The effect of debt policy on firm value. (3) The effect of company growth on firm value. The population in this study are all manufacturing companies listed on the Indonesia Stock Exchange (BEI) 2015-2019. While the sample collection technique in this study used purposive sampling technique with a sample size of 189 samples. The data analysis method used is multiple regression using SPSS 25 software. These results indicate that: (1) Audit opinion has a positive and significant effect on firm value with a significance of $0.007<0.05$. (2) Debt policy has a negative and significant effect on firm value with a significance of 0.001 $<0.05$. (3) Company growth has a positive and insignificant effect on firm value with a significance of $0.155>0.05$.
\end{abstract}

Keywords: Audit opinion; company Growth; debt policy; firm value

How to cite

Fadhillah, Idris \& Afriyenti, Mayar. (2021). Pengaruh Opini Audit, Kebijakan Hutang dan Pertumbuhan Perusahaan terhadap Nilai Perusahaan. Jurnal Eksplorasi Akuntansi, 3(1), 98-111.

\section{PENDAHULUAN}

Secara umum perusahaan adalah organisasi yang didirikan oleh seseorang atau sekelompok orang atau badan lain yang berkegiatan untuk melakukan produksi dan distribusi guna memenuhi kebutuhan ekonomis manusia. Dalam mendirikan perusahaan, pemilik ingin mencapai target-target yang sudah direncanakan demi kelangsungan perusahaan dengan baik. Di era globalisasi seperti sekarang ini, seseorang atau sekelompok yang mendirikan perusahaan untuk membangun suatu usaha semakin banyak di Indonesia.

Hal tersebut dapat di buktikan berdasarkan data di Bursa Efek Indonesia (BEI) sampai akhir tahun 2019 terdapat total 668 perusahaan yang telah mencatatkan sahamnya di pasar modal atau go public termasuk di dalamnya terdapat 189 perusahaan di sector manufaktur yang merupakan jenis perusahaan yang mendominasi di Bursa Efek Indonesia. Yang menunjukkan bahwa salah satu bisnis investasi yang sedang booming di masyarakat Indonesia saat ini adalah investasi dana, yang menyebabkan industri manufaktur berkembang pesat, dan semakin banyak perusahaan yang berpartisipasi memanfaatkan peluang ini.

Pertumbuhan pasar modal Indonesia ditandai dengan banyaknya investor yang menanamkan modalnya pada perusahaan yang bergerak di bidang manufaktur. Hal ini disebabkan meningkatnya kebutuhan akan kebutuhan sehari-hari, sehingga kemungkinan 
terjadinya kerugian sangat kecil. Perkembangan ini membuat produsen di industri manufaktur membutuhkan dana dari dana eksternal, salah satunya adalah untuk menerbitkan saham secara publik dan menjual sahamnya di pasar modal. Menurut Menteri Perindustrian Airlangga Hartono, dibandingkan dengan industri lain, manufaktur atau pengolahan masih menjadi salah satu pendorong utama pertumbuhan ekonomi Indonesia.

Menurut catatan Kementrian Perindustrian, realisasi investasi sector industry pengolahan periode 2015 samapi semester I 2019 berhasil mencatatkan total nilai sebesar Rp. $1,173,5$ triliun. Salah satu realisasi investasi ini dapat dilihat pada program penumbuhan dan pengembangan industry smelter sampai 2019, dimana terdapat 46 perusahaan yang telah berinvestasi sebesar USD 50,4 miliiar dengan penyerapan tenaga kerja langsung lebih dari 64 ribu orang (liputan6.com, 2019).

Fenomena inilah yang mengakibatkan munculnya persaingan ketat antar perusahaan yang mengharuskan perusahaan memiliki kemampuan untuk tetap bertahan dalam usahanya tersebut. Oleh karena itu, persaingan usahan yang kompetitif mengharuskan perusahaan cepat dan tepat dalam mengambil keputusan strateginya. Perusahaan harus memiliki strategi supaya perusahaan tetap berjalan dan mendapatkan keuntungan yang besar dengan meningkatkan mutu dan kualitas produknya. Kalau tidak produk mereka akan tergusur dari pasar dan perusahaan akan mengalami kerugian atau kebangkrutan.

Dengan semakin ketatnya persaingan di era globaliasi ini peningkatan nilai perusahaan yang merupakan tujuan utama yang harus dilakukan. Menurut Septia (2015) tujuan perusahaan jangka pendek yaitu mendapatkan laba maksimal dengan sumber daya yang ada, sementara dalam jangka panjang tujuan utama perusahaan adalah memaksimalkan nilai perusahaan. Nilai perusahaan tersebut tercermin dari harga pasar sahamnya karena penilain investor terhadap perusahaan dapat diamati melalui pergerakan harga saham perusahaan yang ditransaksikan di bursa untuk perusahaan yang sudah go public.

Penelitian tentang nilai perusahaan sudah banyak dilakukan. Seperti penelitian Nisa, dkk (2019) yang berjudul Opini auditor pemoderasi pengaruh good corpotate governance terhadap nilai perusahaan tahun 2015-2017. Yang menggunakan proksi Tobin's Q untuk mengukur nilai perusahaan yang menunjukan hasil GCG yang diproksikan oleh kepemilikan institutional, komite independen, dan komite audit memiliki dampak positif yang signifikan terhadap nilai perusahaan. Opini audit tidak mempengaruhi interaksi antara good corpotate governance yang diproksikan oleh kepemilikan manajerialt terhadap nilai perusahaan. Opini audit memperkuat pengaruh good corpotate governance dengan proksi kepemilikan intitusional, dewan komisaris independen, dan komite audit terhadap nilai perusahaan.

Penelitian yang dilakukan Riska Aprillia (2017) dengan judul price earning ratio, leverage, profitabilitas terhadap nilai perusahaan food dan beverages yang terdaftar di BEI tahun 2012-2015. Yang menggunakan rasio PBV menunjukan hasil setiap variabel berpengaruh signifikan terhadap nilai perusahaan. Penelitian yang dilakukan Wahyuni (2013), ada beberapa aspek yang mempengarungi nilai perusahaaan diataranya keputusan investasi, keputusan pendanaan, kebijakan dividen, pertumbuhan perusahaan, ukuruan perusahaan, profitabilitas, dan kepemilikan institusional. Dari beberapa faktor tersebut ada yang berpengaruh dan ada juga yang tidak berpengaruh terhadap nilai perusahaan.

Nilai perusahaan dapat diukur menggunakan rasio seperti price earning ratio (PER), Tobin's Q dan price to book value (PBV). Price earning ratio (PER) menunjukan berapa jumlah yang dikeluarkan oleh para investor untuk membayar setiap dolar laba yang dilaporkan (Brigham dan Houston, 2006). Kegunaan price earning ratio (PER) adalah untuk melihat bagaimana pasar menghargai kinerja perusahaan yang tercermin oleh earning per share nya, Price earning ratio menunjukan hubungan antara pasar saham biasa dengan earning per share. Penelitian yang diukur menggunakan price earning ratio (PER). Tobin's $\mathrm{Q}$ menunjukan bahwa perusahaan memiliki prospek pertumbuhan yang baik maka akan 
semakin besar kerelaaan investor untuk mengeluarkan pengorbanan yang lebih untuk memiliki perusahaan tersebut (Sukamulja, 2004).

Price to book value (PBV) rasio yang menunjukkan apakah harga saham yang diperdagangkan overvalued (di atas) atau undervalued (di bawah) nilai buku saham tersebut (Fakhruddin dan Hadianto, 2001). Price to book value menggambarkan seberapa besar pasar menghargai nilai buku saham suatu perusahaan. Adapun yang dimaksud dengan nilai buku adalah perbandingan antara modal dengan jumlah saham yang beredar. Menurut konsepnya, rasio Tobin's Q lebih unggul dari pada rasio price earning ratio dan price to book value karena rasio ini berfokus pada beberapa nilai perusahaan saat ini secara relative terhadap berapa biaya yang dibutuhkan untuk menggantinya saat ini. Tetapi dalam prakteknya, rasio Q sulit untuk dihitung dengan akurat karena memperkirakan biaya pengganti atas asset sebuah perusahaan bukanlah suatu pekerjaan yang mudah (Margaretha, 2014). Dalam penelitian ini peneliti menggunakan ratio price to book value (PBV), karena PBV banyak digunakan dalam mengambil keputusan investasi. Selain itu, ada beberapa keunggulan PBV yaitu nilai buku merupakan ukuran yang stabil dan sederhana yang dapat dibandingkan dengan harga pasar.

Dalam meningkatkan nilai perusahaan maka harus ada kerja sama antara kedua belah pihak, yaitu manajemen perusaahan yang diwakili oleh manajer dan pemegang saham. Namun fatanya yang sering terjadi adanya kontradiksi antara manajer perusahaan dengan pemegang saham. Ketika terdapat pemisahan antara pemilik dengan manajer (agen) disuatu perusahan maka terdapat keungkinan bahwwa keinginan pemilik diabaikan. Inilah yang menyebabkan adanya masalah keagenan atau yang sering disebut agency problem (M. Jensen \& Mecklin, 2012).

Susianti dan Yasa (2013) mengemukakan bahwa laporan keuangan merupakan salah satu sumber informasi yang dimiliki oleh suatu perusahaan dan digunakan oleh investor untuk analisis dalam mengambil keputusan. Opini audit yang diberikan oleh auditor independen menjadi salah satu aspek penting dalam evaluasi pemangku kepentingan dalam laporan keuangan perusahaan. Pendapat yang diberikan oleh auditor sebagai penilai independen atas laporan keuangan perusahaan merupakan jenis informasi lain yang dapat digunakan sebagai pedoman bagi pengguna laporan keuangan untuk mengambil keputusan ekonomi, Deegan dalam Purbawati (2016). Purbawati (2016), opini audit atas laporan keuangan menjadi pertimbangan penting ketika investor mengambil keputusan investasi, sehingga auditor sangat handal dalam memberikan informasi yang baik kepada investor.

Laporan audit, sebagai tahap akhir dari proses audit, sangat lah penting dalam setiap penugasan untuk mengkomunikasikan berbagai hasil temuan auditor eksternal. Pengguna laporan keuangan mengandalkan laporan auditor untuk memperoleh keyakinan atas laporan keuangan tersebut. Jika laporan audit yang diterbitkan tidak benar, auditor akan bertanggung jawab. Opini audit akan meningkatkan kepercayaan investor terhadap penerapan informasi keuangan yang disampaikan oleh perusahaan. Perusahaan atau pihak lain membutuhkan informasi laporan keuangan yang diaudit, sehingga opini auditor sangat penting. Dari opini audit yang diberikan oleh auditor independen, dapat dilihat gambaran status perusahaan dari perspektif akuntansi, sehingga opini audit yang terdapat dalam laporan keuangan dapat digunakan sebagai bahan pertimbangan dalam pengambilan keputusan investasi (Hendriani, 2019).

Opini wajar tanpa pengecualian merupakan opini yang paling diinginkan oleh semua klien, karena menegaskan dan memastikan bahwa laporan keuangan yang diberikan oleh manajemen perusahaan tidak mengandung salah saji material dan sesuai dengan standar akuntansi (Ardiana, 2014). Penelitian Purbawati (2016) dan Kurniawati (2016) membuktikan bahwa opini wajar tanpa pengecualian yang diberikan auditor dapat meningkatkan nilai perusahaan. Pasar akan merespon positif opini wajar tanpa pengecualian karena opini tersebut 
menunjukkan bahwa laporan keuangan perusahaan telah disajikan secara wajar sesuai dengan Prinsip Akuntansi Berterima Umum (PABU)

Penelitian mengenani pengaruh opini audit terhadap nilai perusahaan yang dilakukan oleh Sanulika (2018) menyatakan opini audit berpengaruh signifikan terhadap nilai perusahaan. Sedangkan penelitian yang dilakukan Utomo (2018) menyatakan opini audit tidak berpengaruh terhadap nilai perusahaan dengan menggunakan Tobin's Q. Dan penelitian yang dilakukan Diantara dan Suryanara (2019) menunjukan bahwa opini audit tidak berpengaruh terhadap nilai perusahaan dengan menggunakan Tobin's Q.

Selain opini audit, faktor yang mempengaruhi nilai perusahaan adalah kebijakan hutang. Sumail et al. (2013) menyimpulkan bahwa perusahaan di Indonesia cenderung menggunakan hutang dibandingkan modal. Pilihan menggunakan hutang atau modal dapat dijelaskan secara teoritis melalui teori trade-off. Teori trade-off secara singkat menjelaskan bahwa perusahaan cenderung menggunakan hutang untuk meningkatkan nilai perusahaan. Semakin tinggi rasio hutang yang ditetapkan oleh perusahaan pada tingkat tertentu maka semakin tinggi pula nilai perusahaan tersebut, namun apabila tingkat hutang tersebut melebihi rasio hutang yang ditetapkan oleh perusahaan maka nilai perusahaan akan semakin menurun (Pertiwi et al., 2016).

Kebijakan hutang perlu dikelola karena yang terlampau tinggi dapat menurunkan nilai perusahaan (Perdana, 2012). Disini kita bisa memahami bahwa hutang yang terus tumbuh tanpa pengendalian hanya akan menimbulkan penurunan nilai perusahaan. Artinya publik akan ragu ketika perusahaan memiliki kondisi hutang yang extreme leverage, apakah hutang itu bisa dilunaskan atau tidak. Dan disaat keyakinan publik menurun maka reaksi negatif dari pemegang saham akan terlihat yaitu dalam bentuk pelepasan saham (Fahmi, 2012).

Penelitian mengenani pengaruh kebijakan hutang terhadap nilai perusahaan sudah banyak dilakukan. Seperti penelitian yang dilakukan oleh Septariani (2017) yang menyatakan kebijakan hutang (DER) berpengaruh signifikan terhadap nilai perusahaan (PBV). Penelitian Pangaribuan (2019) yang menyatakan kebijakan hutang (DER) berpengaruh positif terhadap nilai perusahaan (Tobin's Q). Sedangkan penelitian yang dilakuakn Pertiwi et al. (2016) dan Pakkekong (2019) menyatakan kebijakan hutang tidak berpengaruh terhadap nilai perusahaan.

Faktor lain yang berkenaan dengan nilai perusahaan adalah pertumbuhan perusahaan. Pertumbuhan merupakan kemampuan perusahaan untuk mempertahankan posisi usahanya dalam perkembangan ekonomi dan industri di dalam perekonomian dimana perusahaan tersebut beroperasi. Secara umum, perusahaan yang tumbuh pesat akan mengkonsolidasikan posisinya di era persaingan yang ketat, menikmati peningkatan penjualan yang signifikan, dan mendapatkan hasil yang positif dengan pangsa pasar yang meningkat (Pratiwi, 2019). Pertumbuhan perusahaan merupakan salah satu faktor internal yang menjelaskan kinerja perusahaan, dan dianggap mempengaruhi fluktuasi nilai perusahaan..

Pertumbuhan perusahaan tersebut dapat diukur melalui tingkat pertumbuhan penjualan, aset, modal, jumlah pegawai dan lain sebagainya. Tingkat pertumbuhan perusahaan merupakan salah satu faktor internal sebagai gambaran dari kinerja perusahaan yang dianggap mampu mempengaruhi naik turunnya nilai perusahaan. Indikator pertumbuhan perusahaan yang digunakan dalam penelitian ini adalah pertumbuhan aset. Pertumbuhan aset didefinisikan sebagai perubahan (penurunan atau kenaikan) total aset yang dimiliki oleh perusahaan. Pertumbuhan aset mengacu pada persentase perubahan aset pada waktu tertentu dibandingkan tahun sebelumnya. Perusahaan yang terus berkembang umumnya memiliki prospek yang bagus, dan investor pasti akan merespon positif hal tersebut yang akan berdampak pada harga saham. Kenaikan harga saham juga berarti peningkatan nilai perusahaan.

Penelitian yang dilakuan mengenai pengaruh pertumbuhan perusahaan sudah banyak dilakukan. Seperti penelitian yang dilakukan Gustiani (2017) yang menyatakan pertumbuhan 
perusahaan (asset growth) berpengaruh positif dan signifikan terhadap nilai perusahaan (PBV). Sejalan dengan penelitian Ramdhona, dkk (2019) yang menyatakan pertumbuhan perusahaan (asset growth) berpengaruh positif dan signifikan terhadap nilai perusahaan (PBV). Hal ini menunjukan bahwa semakin tinggi pertumbuhan asset suatu perusahaaan, maka akan semakin besar nilai perushaaan.

Penelitian ini mengacu kepada penelitian sebelumnya yaitu pada penelitian Nugraha, dkk (2018) yang berjudul pengaruh pertumbuhan perusahaan dan profitabillitas terhadapa nilai perusahaan pada perusahaan sektor property yang terdaftar di Bursa Efek Indonesia periode 2012-2016. Penelitian yang dilakukan oleh Nugraha et al. (2018) hanya menguji pengaruh faktor internal perusahaan terhadap nilai perusahaan. Dalam penelitian ini, peneliti ingin mengetahui bagaimana faktor eksternal perusahaan juga dapat mempengaruhi nilai perusahaan yaitu opini auditor. Dalam penelitian ini peneliti tidak membahas variabel profitabilitas namun menambahkan variabel kebijakan hutang. Variabel profitabilitas tidak digunakan karena hasil yang diperoleh sesuai dengan hasil penelitian sebelumnya.

Dalam penelitian ini peneliti menjadikan perusahaan sektor industri manufaktur yang terdaftar di Bursa Efek Indonesia sebagai sampel penelitian. Dipilihnya satu kelompok industry, yaitu industry manufaktur dimaksud untuk menghindari bias yang disebabkan oleh efek industri (industry effect). Wulandari dan Ramantha (2016) efek industri adalah risiko industri yang berbeda antara sektor industry dengan yang lain. Selain itu sector manufaktur industry merupakan perusahaan yang berskala besar jika dibandingkan dengan sektor lainnya. Dan saham perusahaan manufaktur lebih mudah terpengaruh oleh kondisi perekonomian dan memiliki tingkat sensitifitas yang tinggi terhadap setiap kejadian baik internal maupun ekternal perusahaan. Pemilihan sektor manufaktur juga didasari alasan terkait dengan fenomena yang telah dijelaskan diatas, bahwa sektor ini selalu menjadi yang teratas dari sector lain. Penelitian ini diharapkan dapat memberikan gambaran kepada investor sebelum melakukan investasi terhadap perusahaan yang diinginkan.

Berangkat dari uraian di atas perlu dilakukan kajian mendalam mengenai: (1) pengaruh opini audit terhadap nilai perusahaan, (2) pengaruh kebijakan hutang terhadap nilai perusahaan, (3) pengaruh pertumbuhan perusahaan terhadap nilai perusahaan.

\section{REVIEW LITERATUR}

\section{Teori Keagenan (Agency Theory)}

Agen merupakan pihak yang diberi wewenang oleh prinsipal untuk mengelola aset perusahaan. Pihak prinsipal tersebut memberi kewenangan kepada agen untuk melakukan transaksi atas nama principal dan diharapkan dapat membuat keputusan terbaik bagi principalnya (Hartono, 2004). Kontrak atau hubungan kerja antara prinsipal dan agen dapat menyebabkan ketidakseimbangan informasi (asimetri informasi), yang menyebabkan masalah keagenan. Masalah agensi dapat terjadi karena agen berada pada posisi yang memiliki informasi lebih banyak tentang perusahaan dibandingkan dengan prinsipal (Putri dan Dwija, 2016).

\section{Teori Sinyal (Signaling Theory)}

Signalling theory menekankan kepada kepentingan informasi yang dikeluarkan oleh perusahaan terhadap keputusan investasi pihak luar perusahaan. Informasi yang lengkap, relevan, akurat dan tepat waktu sangat diperlukan oleh investor di pasar modal sebagai alat untuk mengambil keputusan dalam berinvestasi (Wijaya, 2012). Pada saat informasi diumumkan, pihak luar terlebih dahulu mengalisis informasi tersebut sebagai sinyal positif atau negative. Jika sinyal positif investor akan bersedia melakukan perdagangan saham dengan demikian pasar akan bereaksi melalui perubahan dalam voleme perdagangan saham (Suwadjono, 2010). 


\section{Nilai Perusahaan}

Nilai perusahaan adalah presepsi invertor terhadapa tingkatan keberhasilan perusahaan yang sering dikaitkan dengan harga saham. Nilai perusahaan memberikan gambaran kepada manajemen mengenai persepsi investor mengenai kinerja masa lalu dan prospek perusahaan dimasa yang akan datang (Brigham dan Houston, 2003). Sujoko dan Soebiantoro (2007) menjelaskan bahwa nilai perusahaan merupakan persepsi investor terhadap tingkat keberhasilan perusahaan yang sering dikaitkan dengan harga saham. Dalam penelitian ini nilai perusahaan didefinisikan sebagai nilai pasar dengan menggunakan rasio price to book value (PBV). Alasan menggunakan rasio PBV karena PBV menunjukkan seberapa jauh suatu perusahaan mampu menciptakan nilai perusahaan yang relatif terhadap jumlah modal yang diinvestasikan.

\section{Opini Audit}

Opini yang diberikan merupakan pernyataan kewajaran, dalam semua hal yang material, posisi keuangan, hasil usaha dan arus kas sesuai dengan prinsip akuntansi berterima umum (IAI 2002). Pendapat atau opini audit merupakan bagian yang tidak terpisahkan dari laporan audit. Opini audit diberikan oleh auditor melalui beberapa tahap audit sehingga auditor dapat memberikan pendapat atas laporan keuangan yang diuaditnya. Arens et al (2006) mengemukankan bahwa laporan audit adalah langkah terakhir dari seluruh proses audit. Dengan demikian, auditor dalam meberikan opini sudah didasarkan pada keyakinan profesionalnya.

Dalam teori agensi, auditor independen dianggap bisa menjadi pihak penengah dalam perbedaan kepentingan antara pihak prinsipal dengan pihak agen dalam mengelola presuahaan. Auditor harus bertanggung jawab atas pendapat yang dikemukakan karena akan mempengaruhi keputusan pengguna laporan keuangan. Ketika auditor eksternal memiliki independensi yang cukup untuk menghasilkan informasi yang mencerminkan keadaan keuangan sebenarnya dari perusahaan klien, konflik keagenan dapat dikurangi (Martinez, 2014).

\section{Kebijakan Hutang}

Jika suatu perusahaan mempunyai jumlah hutang yang besar dalam struktur permodalannya dianggap beresiko, namun sebaliknya jika perusahaan menggunakan sedikit atau tidak ada hutang, dianggap perusahaan tidak dapat menggunakan tambahan modal eksternal yang dapat meningkatkan operasional perusahaan (Mamduh dan Abdul, 2005). Pemegang saham atau investor lebih menyukai perusahaan yang menggunakan hutang pada level tertentu sehingga harapan pemilik perusahaan dapat terpenuhi. Selain itu, perilaku manajer dan komisaris perusahaan juga dapat dikendalikan (Hasni, 2013).

Teori sinyal menjelaskan bahwa perusahaan yang menambah hutang dapat dipandang sebagai perusahaan yang percaya diri dengan prospek masa depan perusahaan. Pihak luar juga dapat mengartikan peningkatan hutang sebagai kemampuan perusahaan untuk membayar hutang dimasa yang akan datang atau mengurangi resiko bisnis, sehingga peningkatan hutang akan mengirimkan sinyal yang positif (Brigham dan Houston, 2011).

\section{Pertumbuhan Perusahaan}

Menurut Helfert (1997) pertumbuhan (growtf) adalah dampak atas arus dan perusahaan dari perubahan operasional yang disebabkan oeh pertumbuhan atau penurunan volume usaha. Menurut Susanto (1997) pada umumnya perusahaan yang tumbuh dengan cepat memperoleh hasil positif dalam artian pemantapan posisi dipersaingan, menikmati penjualan yang meningkat secara signifikan dan diiringi peningkatan pangsa pasar. Perusahaan yang tumbuh juga aan mendapat keuntungan lain yaitu citra yang positif. 
Safrida (2008) menyatakan bahwa pertumbuhan perusahaan mempunyai pengaruh langsung dan positif terhadap perubahan harga saham, artinya investor bereaksi positif terhadap informasi tentang pertumbuhan perusahaan, yang dapat meningkatkan nilai perusahaan. Oleh karena itu, semakin tinggi tingkat pertumbuhan perusahaan maka semakin tinggi pula nilai perusahaan tersebut. Di sisi lain, semakin rendah tingkat pertumbuhan perusahaan, semakin rendah nilai perusahaan.

\section{METODE PENELITIAN}

Jenis penelitian yang digunakan dalam penelitian ini adalah penelitian kausatif. Penelitian kausatif adalah penelitian yang bertujuan untuk menunjukan arah hubungan sebab akibat antara variable bebas dan variable terikat (Sugiyoni, 2016). Populasi adalah keseluruhan elemen yang terdiri dari atas objek atau subjek yang mempunyai kualitas dan karakteristik tertentu yang ditetapkan oleh peneliti untuk dipeljari dan kemudian ditarik kesimpulan. Dimana dalam penelitian ini populasinya adalah seluruh perusahaan manufaktur yang terdaftar di BEI tahun 2015 sampai dengan tahun 2019.

Sampel adalah bagian dari jumlah dan karakteristik yang dimiliki oleh populasi. Penelitian ini menggunakan sampel yaitu perusahaan manufaktur yang terdafar di BIE pada tahun 2015-2019. Sampel dipilih menggunakan purposive sampling. Purposive sampling merupakan pemilihan sampel berdasarkan kriteria. Dalam penelitian ini terdapat 46 perusahaan dari 189 sampel.

\section{Defenisi Variabel dan Pengukurannya Nilai Perusahaan (Y)}

Nilai perusahaan adalah tujuan yang dicapai oleh perusahaan yang akan diberikan kepada investor agar investor tidak salah mengambil keputusan dalam mebeli saham perusahaan dan memberikan kemakmuran kepada pemegang saham. Nilai perusahaan diukur menggunakan price to book value (PBV). Rasio ini merupakan perbandingan antara harga saham dengan nilai buku ekuitas. PBV dapat dirumuskan sebagai berikut :

$$
\mathrm{PBV}=\frac{\text { Harga Saham per Saham }}{\text { Nilai Buku per Lembar Saham }}
$$

\section{Opini Audit (X1)}

Opini audit diartikan sebagai pendapat yang diberikan oleh auditor pada perusahaan atas permeriksaan yang dilakukan pada laporan keuangan perusahaan. Opini auditor pada penelitian ini diukur dengan mengunakan variabel dummy yaitu angka 1 (satu) diberikan untuk perusahaan yang laporan keuangannya memperoleh opini wajar tanpa pengecualin (unqualified opinion) dan kategori 0 diberikan untuk perusahaan yang laporan keuangannya memperoleh opini selain wajar tanpa pengecualian (selain unqualified opinion). Skala data yang digunakan data nominal.

\section{Kebijakan Hutang (X2)}

Kebijakan hutang merupakan kebijakan yang diambil oleh perusaahan dalam pembiayaan aktivitas operasional perusahaan yang bersumber dari eksternal perusahaan. Kebijakan hutang merupakan suatu kebijakan yang diambil oleh manajemen untuk mendapatkan sumber pembiayaan perusahaan sehingga dapat digunakan untuk mendanai kegiatan operasional perusahaan (Riyanto, 2004). Selain itu, kebijakan hutang perusahaan juga dapat menjadi mekanisme pengawasan bagi manajer untuk memantau perilaku manajemen perusahaan. Kebijakan hutang dalam penelitian ini diukur dengan proksi seperti berikut: 


$$
\mathrm{DER}=\frac{\text { Total Hutang }}{\text { Total Ekuitas }}
$$

\section{Pertumbuhan Perusahaan}

Pertumbuhan perusahaan diukur dengan menggunakan perubahan total aktiva. Pertumbuhan aktiva adalah selisih total aktiva yang dimiliki perusahaan pada periode sekarang dengan periode sebelumnya terhadap total aktiva periode sebelumnya. Pengukuran perubahan total aktiva dapat di persentasekan.

$$
\text { Asset growth }=\frac{\text { Total Aset }_{\mathrm{t}}-\text { Total Aset }_{\mathrm{t}-1}}{\text { Total Aset }_{\mathrm{t}-1}} \times 100 \%
$$

\section{Teknik Analisis Data}

Penelitian ini menggunakan teknik analisis regresi linear berganda. Analisis regresi berganda adalah analisis tentang hubungan antara satu dependent variabele dengan dua atau lebih independent variabel. Data yang telah dikumpulkan akan dioalah dengan menggunakan SPSS. Untuk mengetahui pengaruh variabel bebas terhadap variabel terkait digunakan model regresi berganda degan persamaan sebagai berikut :

$$
P B V=a+b_{1} X_{1}+b_{2} X_{2}+b_{3} X_{3}+e
$$

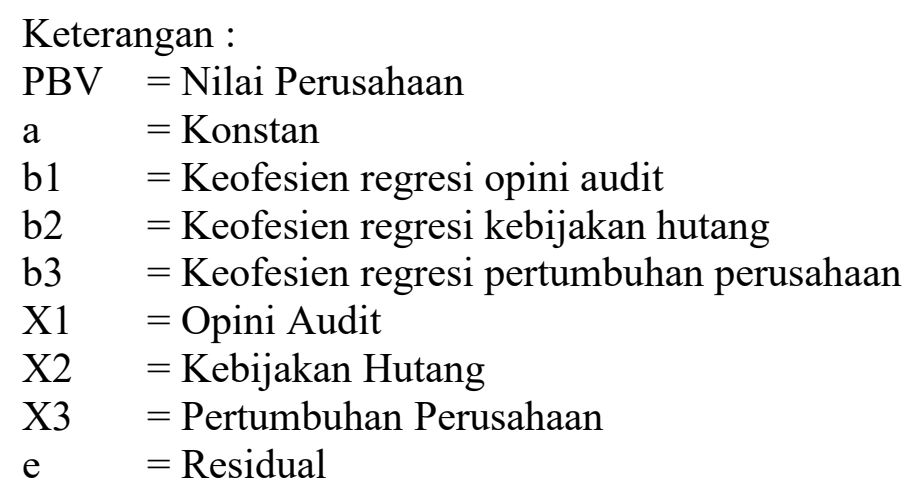

\section{HASIL DAN PEMBAHSAN}

Deskripsi variabel dalam statistik deskriptif yang digunakan dalam penelitian ini meliputi nilai minimum, maksimum, mean dan standar deviasi dari variabel penelitian. Statistik deskriptif menggambarkan karakter sampel yang digunakan dalam penelitian ini. Statistik deskriptif selengkapnya dalam penelitian ini ditampilkan dalam tabel 1 berikut:

Tabel 1. Statistik deskriptif variabel penelitian Descriptive Statistics

\begin{tabular}{llrrrr}
\hline & N & \multicolumn{1}{c}{ Minimum } & Maximum & \multicolumn{1}{c}{ Mean } & Std. Deviation \\
\hline Opini_Audit & 189 & .00 & 1.00 & .6878 & .46461 \\
Kebijakan_Hutang & 189 & .04 & 4.55 & .6890 & .64232 \\
Pertumbuhan_Perusahaan & 189 & -.32 & .93 & .0969 & .16350 \\
Nilai_Perusahaan & 189 & .10 & 11.06 & 2.0479 & 1.93721 \\
Valid N (listwise) & 189 & & & & \\
\hline
\end{tabular}

Sumber: Hasil Olahan SPSS 25

Data yang digunakan pada penelitian ini berjumlah 189 sampel. Berdasarkan tabel 8 pada variabel opini audit (X1) dapat dijelaskan bahwa opini audit terdiri dari 0 untuk perusahaan yang laporan keuangannya memperoleh opini selain wajar tanpa pengecualian 
(selain unqualified opinion) dan 1 untuk perusahaan yang laporan keuangannya memperoleh opini wajar tanpa pengecualian (unqualified opinion). Pada variabel kebijakan hutang (X2) dapat dijelaskan bahwa nilai terendah (minimum) sebesar 0,04 dan tertinggi (maksimum) sebesar 4,55. Adapun rata-rata kebijakan hutang adalah 0,6890 dan standar deviasi 0,64232. Pada variabel pertumbuhan perusahaan (X3) dapat dijelaskan bahwa nilai terendah (minimum) sebesar -0,32 dan tertinggi (maksimum) sebesar 0,93. Adapun rata-rata pertumbuhan perusahaan adalah 0,0969 dan standar deviasi 0,16350. Dan pada variabel nilai perusahaan (Y) dapat dijelaskan bahwa nilai terendah (minimum) sebesar 0,10 dan tertinggi (maksimum) sebesar 11,06. Adapun rata-rata nilai perusahaan adalah 2,0479 dan standar deviasi 1,93721.

\section{Uji Normalis}

Uji normalitas merupakan suatu bentuk pengujian tentang kenormalan distribusi data. Uji normalitas digunakan untuk mengetahui apakah residual yang diteliti berdistribusi normal atau tidak. Grafik normal probability plot ditunjukkan pada gambar berikut:

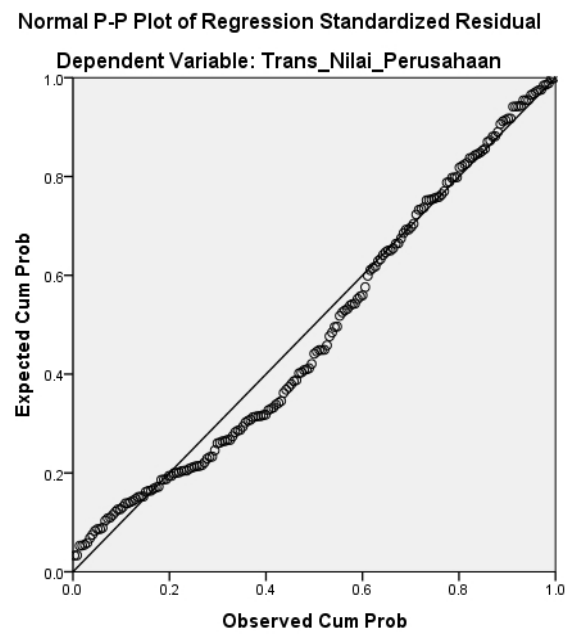

\section{Gambar 1. Grafik normal probability plot}

Pada gambar 1 dapat dilihat bahwa grafik normal probability plot menunjukkan pola grafik yang normal. Hal ini terlihat dari titik yang menyebar di sekitar grafik normal. Hal ini terlihat dari titik-titik yang menyebar disekitar garis diagonal dan penyebarannya mengikuti garis diagonal. Oleh karena ini dapat disimpulkan bahwa model regresi layak diapakai karena memenuhi asumsi normalitas.

\section{Uji Multikolinearitas}

Uji multikolineritas bertujuan untuk mengetahui ada tidaknya variabel independen yang memiliki korelasi antar variabel independen lain dalam satu model. Model regresi yang baik seharusnya tidak terjadi korelasi diantara variabel independen. Multikolineritas diuji dengan melihat nilai Tolerance yang tidak kurang dari 0,1 dan nilai Variance Inflation Factor (VIF) yang tidak lebih dari 10 sehingga model dapat dikatakan terbebas dari multikolineritas. Hasil uji multikolinearitas dapat dilihat pada tabel 2 dibawah ini: 
Tabel 2. Hasil uji multikolinearitas

Coefficients $^{\mathrm{a}}$

\begin{tabular}{|ll|r|c|}
\hline \multirow{2}{*}{ Model } & \multicolumn{2}{|c|}{ Collinearity Statistics } \\
\cline { 3 - 4 } & & Tolerance & VIF \\
\hline 1 & (Constant) & & \\
& Opini_Audit & .960 & 1.042 \\
& Kebijakan_Hutang & .989 & 1.011 \\
& Pertumbuhan_Perusahaan & .954 & 1.048 \\
\hline
\end{tabular}

a. Dependent Variable: Trans Nilai Perusahaan

Sumber : Hasil Olahan SPSS 25

Berdasarkan tabel 2 di atas dapat dilihat bahwa model regresi tidak mengalami gangguan multikolinieritas. Hal ini tampak pada nilai tolerance masing-masing variabel lebih besar dari 10 persen $(0,1)$. Hasil perhitungan VIF juga menunjukkan bahwa nilai VIF masingmasing variabel kurang dari 10. Jadi dapat disimpulkan bahwa tidak ada multikolinieritas antar variabel bebas dalam model regresi tersebut.

\section{Uji Heteroskedastisitas}

Pengujian heteroskesdastisitas dilakukan untuk melihat apakah terdapat ketidaksamaan ragam dari residual satu ke pengamatan ke pengamatan yang lain. Kondisi heteroskedastisitas biasanya muncul pada data cross-sectional, atau pada data yang diperoleh dari beberapa responden pada waktu tertentu. Model regresi yang memenuhi syarat adalah residual suatu observasi sama dengan residual observasi lainnya yaitu tetap atau disebut mean square error. Salah satu cara untuk mendeteksi heteroskedastisitas adalah dengan melihat scatter plot dan menggunakan uji gletser. Jika pada grafik titik-titik membentuk pola tertentu yang teratur seperti gelombang besar melebar, kemudian menyempit maka telah terjadi heteroskedastisitas. Jika titik-titik menyebar diatas dan dibawah angka 0 pada sumbu Y tanpa membentuk pola tertentu, maka tidak terjadi heteroskedastisitas. Hasil uji heteroskedastisitas dari program SPSS dapat dilihat pada gambar 2 berikut ini:

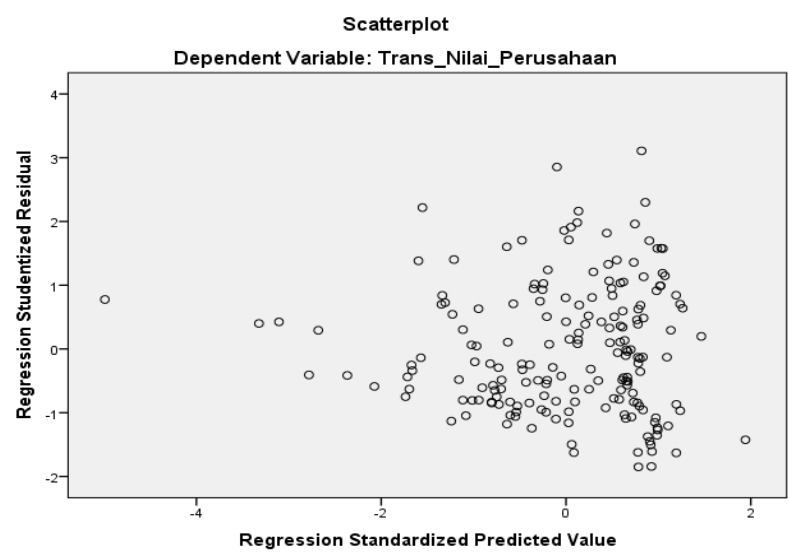

Gambar 2. Grafik scatter plot

Pada gambar 2 dapat dilihat bahwa titik-titik pada grafik scatterplot tidak mempunyai pola penyebaran yang jelas dan titik-titik tersebut menyebar di atas dan dibawah angka 0 pada sumbu Y. Hal ini menunjukkan bahwa tidak terdapat gangguan heteroskedastisitas pada model regresi. 


\section{Uji Autokorelasi}

Uji autokorelasi bertujuan untuk menguji apakah dalam suatu model regresi linear ada korelasi antara kesalahan pengaganggu pada periode t-1 (sebelumnya). Jika terjadi korelasi maka dinamakan ada problem autokorelasi. Uji autokorelasi dapat dilihat dari nilai Durbin Watson. Apabila nilai Durbin Watson berada pada daerah dU sampai 4-dU dapat disimpulkan bahwa model regresi tidak mengandung autokorelasi. Berikut hasil uji autokorelasi ditunjukkan pada Tabel 3.

Tabel 3. Hasil Uji Autokorelasi

\begin{tabular}{|l|r|r|c|r|r|}
\hline \multicolumn{7}{|c|}{ Model Summary $^{\mathbf{b}}$} \\
\hline Model & $\mathrm{R}$ & R Square & $\begin{array}{c}\text { Adjusted R } \\
\text { Square }\end{array}$ & $\begin{array}{c}\text { Std. Error of the } \\
\text { Estimate }\end{array}$ & Durbin-Watson \\
\hline 1 & $.307^{\mathrm{a}}$ & .094 & .079 & .60904 & .706 \\
\hline
\end{tabular}

a. Predictors: (Constant), Pertumbuhan_Perusahaan, Kebijakan_Hutang, Opini_Audit

b. Dependent Variable: Trans_Nilai_Perusahaan

Sumber : Hasil Olahan SPSS 25

Berdasarkan hasil uji autokorelasi pada Tabel 3 diperoleh nilai durbin-watson stat yaitu sebesar 0,706. Dikarenakan angka D-W berada diantara -2 sampai 2 maka dapat disimpulkan bahwa model tidak mengandung autokorelasi.

\section{Analisis Regresi Linear Berganda}

Berdasarkan hasil regresi dengan menggunakan program SPSS, maka didapatkan koefisien regresi yang dapat dilihat pada tabel 4 berikut ini:

Tabel 4. Hasil Koefisien Regresi Linear Berganda Coefficients $^{\mathrm{a}}$

\begin{tabular}{|c|c|c|c|c|c|}
\hline \multirow[b]{2}{*}{ Model } & \multicolumn{2}{|c|}{ Unstandardized Coefficients } & \multirow{2}{*}{$\begin{array}{c}\begin{array}{c}\text { Standardized } \\
\text { Coefficients }\end{array} \\
\text { Beta }\end{array}$} & \multirow[b]{2}{*}{$\mathrm{t}$} & \multirow[b]{2}{*}{ Sig. } \\
\hline & $\mathrm{B}$ & Std. Error & & & \\
\hline (Constant) & 1.228 & .098 & & 12.533 & .000 \\
\hline Opini_Audit & .268 & .098 & .197 & 2.751 & .007 \\
\hline Kebijakan_Hutang & -.243 & .070 & -.246 & -3.501 & .001 \\
\hline Pertumbuhan_Perusahaan & .397 & .278 & .102 & 1.427 & .155 \\
\hline
\end{tabular}

a. Dependent Variable: Trans_Nilai_Perusahaan

Sumber : Hasil Olahan SPSS 25 berikut:

Berdasarkan pada tabel 4 maka didapatkan persamaan regresi linier berganda sebagai

$$
Y=1,228+0,268 \times 1-0,243 \times 2+0,397 \times 3+\text { error }
$$

\section{Koefisien Determinasi}

Koefisien determinasi $\left(\mathrm{R}^{2}\right)$ dilakukan untuk melihat adanya hubungan yang sempurna atau tidak, yang ditunjukkan pada apakah perubahan variabel independen konpensasi dan kedisiplinan akan diikuti oleh variabel dependen kualitas pelayanan pada proporsi yang sama. 
Tabel 5. Hasil Koefisien Determinasi

Model Summary

\begin{tabular}{|c|c|c|c|c|c|}
\hline odel & $\mathrm{R}$ & R Square & $\begin{array}{c}\text { Adjusted R } \\
\text { Square } \\
\end{array}$ & $\begin{array}{l}\text { Std. Error of the } \\
\text { Estimate } \\
\end{array}$ & Durbin-Watson \\
\hline 1 & $.307^{\mathrm{a}}$ & .094 & .079 & .60904 & .706 \\
\hline
\end{tabular}

a. Predictors: (Constant), Pertumbuhan_Perusahaan, Kebijakan_Hutang, Opini_Audit

b. Dependent Variable: Trans_Nilai_Pe-rusahaan

Sumber : Hasil Olahan SPSS $\overline{2} 5$

Berdasarkan tabel 5 dapat dilihat bahwa nilai Adjusted $R^{2}$ adalah sebesar 0,079 . Hal ini dapat diartikan bahwa variabel independen opini audit (X1), kebijakan hutang (X2) dan pertumbuhan perusahaan (X3) dapat menjelaskan variabel dependen nilai perusahaan (Y) sebesar 7,9\%, sedangkan sisanya diterangkan oleh faktor lain yang tidak diteliti.

\section{SIMPULAN, KETERBATAN, DAN SARAN Simpulan}

Penelitian ini menganalisis pengaruh opini audit, kebijakan hutang dan pertumbuhan perusahaan terhdapa nilai perusahaan yang terdaftar di BEI pada periode 2015-2019. Berdasarkan pendahuluan, kajian teori dam pengo;ahan data serta pembahasan terkait hasil pengolahan data yang telah dikaji pada bab terdahulu, maka peneliti menyimpulkan bahwa :

1. Opini audit berpengaruh signifikan terhadap nilai perusahaan manufaktur yang terdaftar di BEI tahun 2015-2019. Hal ini menunjukan opini audit berbanding lurus dengan nilai perusahaan. Jikan opini audit yang didapat baik maka nilai perusahaan juga akan mengalami peningkatan, begitu juga sebaliknya.

2. Kebijakan hutang berpengaruh signifikan terhadap nilai perusahaan manufaktur yang terdaftar di BEI tahun 2015-2019. Hal ini menunjukan kebijakan hutang berbanding lurus dengan nilai perusahaan. Jika hutang meningkat, maka dapat dilihat sebagai perusahaan yang percaya dengan prospek masa depan perusahaan, yang dapat meningkatkan nilai perusahaan.

3. Pertumbuhan perusahaan tidak berpengaruh signifikan terhadap nilai perusahaan manufaktur yang terdaftar di BEI tahun 2015-2019. Hal ini menunjukan bahwa pertumbuhan perusahaan memiliki pengaruh yang kecil namun belum mampu untuk meningkatkan nilai perusahaan.

\section{Keterbatasan}

Peneliti telah berusaha merancang dan mengembangkan penelitian sedemikian rupa, namun masih ada beberapa keterbatasan dalan penelitian ini antara lain:

1. Sampel yang digunakan dalam penelitian ini hanya perusahaan manufaktur, sehingga hasil penelitian ini tidak dapat digunakan sebagai dasar generalisasi.

2. Nilai Adjusted $\mathrm{R}^{2}$ yang menunjukan bahwa masih banyak variable lain yang benar-benar memiliki kontribusi dalam mempengaruhi nilai perusahaan.

3. Proksi yang digunakan sebagai alat ukur nilai perusahaan hanya menggunakan Price to Book Value (PBV). Dengan proksi yang digunakan, memungkinkan terjadinya kelemahan dalam mengukur nilai perusahaan yang hanya berdasar pada harga saham.

\section{Saran} berikut:

Adapun saran untuk penelitian selanjutnya berdasarkan penelitian ini adalah sebagai

1. Untuk penelitian selanjutnya, agar dapat memperluas sampel pengamatan atau pengamatan pada cross-section lainnya seperti pada industri atau sektor lain. 
2. Penelitian selanjutnya disarankan untuk menggunakan factor ekternal perusahaan lainnya sebagai variable independen seperti tingkat suku bunga, tingkat inflansi, kurs mata uang, dan situasi politik yang mempengaruhi nilai perusahaan

3. Penelitian selanjutnya juga dapat menggunakan proksi lain sebagai alat ukur nilai peruahaan, seperti proksi Tobins-Q, dan Price Earnign Ratio (PER).

\section{DAFTAR PUSTAKA}

Ardiana, P. A. (2014). The Role of xternal udit in Improving Firm's alue: Case of Indonesia. In the 5th International Conference of the Japanese Accounting Review. Kobe.

Arens, A.A, Elder, R, J. A and Beasley, M.S. (2003). Auditing and Assurance Service: An Intergrated Approach. Ninth Edition. Prentice Hall. New Jersey.

Diantara, K.I, dan Suryanawa, I.K. (2019). Pengaruh Opini Auditor dan Pertumbuhan Penjualan Perusahaan pada Nilai Perusahaan. E-Jurnal Akuntansi Universitas Udayana. 26(2), 1103-1131.

Fahmi, I. (2018). Pengantar Manajemen Keuangan. Bandung. Alfabeta.

Gustian, D. 2017. Pengaruh Pertumbuhan, Keputusan Investasi, dan Keputusan Pendanaan Terhadap Nilai Perusahaan.Skripsi. Universitas Negeri Padang.

Hasni Y. 2013. Pengaruh Tingkat Profitabilitas, Struktur Asset, dan Growth Oppourtunity Terhadap Struktur Modal Pada Perusahaan Manufaktur yang Telah Go Public Di BEI. Skripsi. UNSRI

Hendriani, M. (2019). Opini Audit Sebagai Pemoderasi Pengaruh Intellectual Capital, Profitabilitas dan Leverage Terhadap Nilai Perusahaan. Jurnal Ekonomi dan Bisnis, $6(2)$

Helfert, E.A. (1997). Teknik Analisis Keuangan. Penerjemah Herman Wibowo. Edisi Kedelapan.Jakarta: Erlangga.

https://www.cnbcindonesia.com/market/20190329075353-17-63576/tiga-pilar-dan-dramapenggelembungan-dana

https://m.liputan6.com/bisnis/read/4090079/industry-manufaktur-sumbang-investasi-rp-11735-triliun

IAI. (2002). Standar Profesional Akuntan Publik. Salemba Empat: Jakarta.

Jensen, M. C., \& Meckling, W. H. (1979). Theory of the firm: Managerial behavior, agency costs, and ownership structure. In Economics social institutions, (163-231).

Jensen, M., \& Meckling, W. (2012). Theory of the firm: Managerial behavior, agency costs, and ownership structure. In The Economic Nature of the Firm: A Reader, Third Edition.

Kurniawati, H. (2016). Pengaruh Board Size, Leverage, dan Kualitas Audit terhadap Nilai Perusahaan. Jurnal Keuangan Dan Perbankan, 12(2), 110- 127.

Martinez, A. L. (2014). Association Between Independent Auditor Fees and Firm Value: a Study of Brazilian Public Companies. Journal of Modern Accounting and Auditing, 10(4), 442-450.

Mamduh M. H dan Abdul H. (2005). Analisis Laporan Keuangan. Yogyakarta.

Nugraha, ddk. (2018). Pengaruh Pertumbuhan Perusahaan dan Profitabilitas Terhadap Nilai Perusahaan pada Perusahaan Sektor Properti yang Terdaftar Di BEI. Artikel Ilmiah. Sekolah Tinggi Ilmu Ekonomi Pasuruan Bandung.

Pakekong, Mentari I, Sri M, dan Paulina V.R. (2019). Pengaruh Struktur Kepemilikan, Kebijakan Dividend an Kebijakan Hutang Terhadap Nilai Perusahaan pada Perusahaan Asuransi yang Terdaftar di BEI Peruiode 2012-2016. Jurnal EMBA 7(1), 611-620

Perdana, S. 2012. Pengaruh Kebijakan Hutang Jangka Panjang dan Kebijakan Dividen Terhadap Nilai Perusahaan, Artikel Ilmiah. 
Pertiwi, et al. (2016). Pengaruh Kebijakan Hutang, Keputusan Investasi dan Profitabilitas Terhadap Nilai Perusahaan Food And Beverages yang Terdaftar Di Bursa Efek Indonesia. Jurnal Emba. 4 (1), 1369-1380

Pangaribun, dkk. (2019). Kebijakan Hutang dan Kebijakan Hutang Terhadap Nilai Perusahaan Pada Sektor Rekok yang Terdaftar Di Bursa Efek Indonesia. Jurnal Akuntansi Published by Program Studi Akuntansi STIE Sultan Agung 5(2): 80-90.

Purbawati, D. (2016). Pengaruh Opini Audit dan Luas Pengungkapan Sukarela terhadap Perubahan Harga Saham. Jurnal Administrasi Bisnis, 5(1), 6-12.

Safrida, E. 2008. Pengaruh Struktur Modal dan Pertumbuhan Perusahaan terhadap Nilai Perusahaan pada Perusahaan Manufaktur di BEI. Thesis. Medan: Universitas Sumatera Utara.

Septia, A W. 2015. Pengaruh Profitabilitas, Keputusan Investasi, Keputusan Pendanaan, Dan Kebijakan Dividen Terhadap Nilai Perusahaan Pada Perusahaan Manufaktur Yang Terdaftar Di Bursa Efek Indonesia. Skripsi. Universitas Negeri Yogyakarta.

Sukamulja, S. (2004). Good Corporate Governance Di Sektor Keuangan: Dampak GCG Terhadap Kinerja Perusahaan (Kasus di Bursa Efek Jakarta). Jurnal Manajemen Dan Bisnis BENEFIT

Sujoko, \& Soebiataro, U. (2007). Shareholding Structure influence Leverage Factor Internal And External Factors Against Value Company (empirical study on the manufacturing and non-manufacturing companies in Jakarta Stock Exchange). Journal of Management and Entrepreneurship.

Sumail, La Ode; Moeljadi; Atim Djazuli; \& Solimun. (2013). Relationship between Insider Ownership and Sales Growth with Dividend Policy and Leverage(Study on Manufacturing Company in Indonesia Stock Exchange). International Journal of Business and Management Invention4(5): 40-49.

Susianti, M., \& Yasa, G. W. (2013). Pengaruh Kinerja Keuangan terhadap Nilai Perusahaan dengan Pemoderasi Good Corporate Governance dan Corporate Social Responsibility. E-Jurnal Akuntansi Universitas Udayana, 3(1), 73-91.

Syardiana, dkk (2015). Pengaruh Investment Opportunity Set, Struktur Modal, Pertumbuhan Perusahan, dan Return On Asset Terhadap Nilai Perusahaan. Akuntavilitas, VII(1).

Utomo, M. P. 2018. Pengaruh Good Corporate Governance, Struktur Modal, Opini Audit, Pergantian Manajemen, Keputusan Investasi, Komite Audit, Terhadap Nilai Perusahaan. Skripsi. Universitas Sumatera Utara.

Wijaya, L., R., P., dan Wibawa, B., A. (2010). Pengaruh Keputusan Investasi, Keputusan Pendanaan, dan Kebijakan Deviden Terhadap Nilai Perusahaan. Simposium Nasional Akuntansi XIII Purwokerto. Universitas Jendral Sudirman Purwokerto.

Wulandari, A. A., \& Ramantha, I. W. (2016). Dampak Moderasi Profitabilitas terhadap Pengaruh Corporate Social Responsibility pada Nilai Perusahaan Manufaktur. EJurnal Ekonomi Dan Bisnis Universitas Udayana, 5(7), 1889-1918.

www.idx.co.id

www.iapi.or.id 